\title{
2018 (平成30) 年融雪期に発生した福島県喜多方市揚津地区における地すべり災害
}

Snowmelt-induced landslide disaster -2018 Agatsu landslide in Kitakata City, Fukushima Prefecture-

柴崎達也 Tatsuya SHIBASAKI／国土防災技術株式会社 Japan Conservation Engineers \& Co., Ltd.

八木浩司 Hiroshi YAGI/山形大学地域教育文化学部 Yamagata University

(公社) 日本地すべり学会東北支部揚津地すべり調査団* Tohoku branch, Japan Landslide Society

\section{1.はじめに}

本年融雪期に福島県喜多方市高郷町揚 津（あがつ）地区で発生した地すべりの 報道を受け, 東北支部では緊急調査団(八 木団長含め計20名）を組織し，5月31日 （5/31）に現地調査を実施した。当日は, 揚津地すべり防止区域を所管する福島県 会津農林事務所より, 発生の経緯や現状 に関し現地説明を受けた後, 2 時間ほど の現地調査を実施した。その後, 喜多方 市高郷総合支所で県および市の関係者同 席のもと会議を行い，地すべりの機構お よび対策に関し参加者で議論しながら意 見集約を行った。調查団としての見解や 提言のレポートをとりまとめ，翌日には 管理者に報告を行った。その後，応急対 策工事が本格化するまで, 少人数メン バーで $6 / 9,6 / 15$ と，ドローン空撮に よる動態調査を実施し, 支部ホームペー ジなどで経過を報告した。本報告では, 6 月中旬までの追加調查の情報も含めて当 地すべりの発生経緯や現時点で推察され る発生機構を速報する。

\section{2. 地すべりの発生経緯}

4/20に県道をパトロールしていた道 路管理者が路面に亀裂を発見した。その 後, $4 / 26$ に連絡を受けた会津農林事務所 により地すべりの監視が進められてきた。 $5 / 17$ に民家側の斜面にも亀裂が生じ 地すべり現象が顕在化してきたことを受 け， $5 / 25 に は$ 市に地すべり対策本部が設

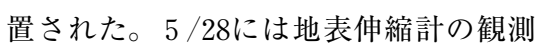
で, 一般的な避難基準とされる $4 \mathrm{~mm} / \mathrm{h}$ の移動速度に達し，5/29に一世帯二人に 避難勧告が出された。地すべりの報道を
受けて調査団を派遣した $5 / 31$ も $3 \mathrm{~mm} /$ $\mathrm{h}$ 程度の移動が継続していた（写真 -1$)$ 。 その後も地すべり活動が続いていたが, 6 月中旬から本格化した沢水の迂回や ディープウェルによる強制排水工の効果 で，この原稿執筆中の $6 / 20$ 時点では, 移動速度の低減が確認されてきている。

\section{3. 地すべり現象と発生機構}

今回変動した阿賀川に面す地すべりブ ロックは, 背後を含む大きな地すべり地 形内で分化した末端のブロックが再活動 したものと判断される (図-2)。主要 な亀裂は, ほぼ既存の地すべり地形の輪 郭に沿って分布する。

地すべりの発生誘因としては, 末端の 河川による侵食や地下水の影響が考えら れる。現状のデータだけでは確定できな いが，4 月下旬に地すべりの兆候がみら れ, 5 月に変状が顕在化した要因として 融雪の影響が考えられる。調查地周辺に
は数多くの地すべりが分布し, それらの 調査・観測データが当学会誌にも一部が 公表されている。現場から約 $6 \mathrm{~km}$ ぼ 北西に位置する滝坂地すべりでの地下水 観測事例（相楽ほか, 2003 ; 相楽ほか, 2005 ; 吉松ほか, 2012）によれば, 3 月中 旬〜 4 月上旬に地下水位が最も上昇する ことが判明している。図ー 1 に示した過 去 3 年間の最寄りの気象観測所 (西会津) のデータによると, 本年は過去 3 年間で 積雪量や年間降水量が最も高かったこと もあり，融雪が地すべり発生に影響した 可能性が考えられる。

地すべり末端部は, 蛇行する阿賀川の 水衝部に当たり, 地すべりの押し出しに 伴うと思われる河岸の崩壊が進行してい た。河岸斜面内に亀裂も多数確認され, 河川への落石も観察された。空撮画像の 経日変化からも河岸斜面の裸地化の進行 が確認できた。今後河岸斜面の崩壊が背 後の地すべりを助長しないような対策が

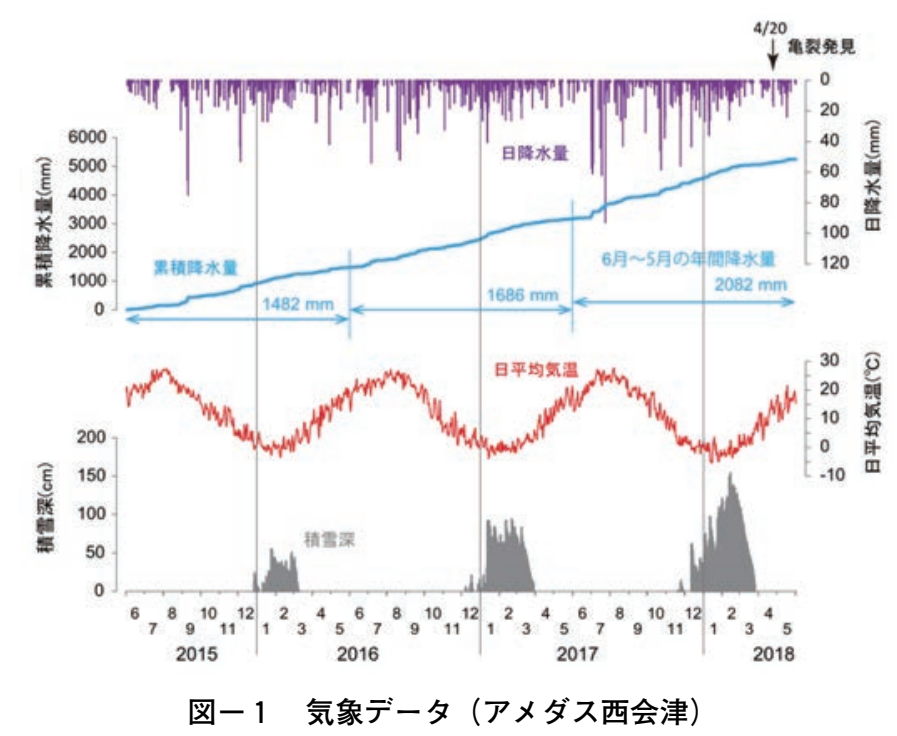

* (公社) 日本地すべり学会東北支部揚津地すべり調查団 $5 / 31$ 調査/団長:八木浩司 (山形大学), 副団長:柴崎達也 (国土防災技術), 団員:奥山武彦 (山形大学), 阿部真 郎, 山田孝雄, 林一成 (奥山ボーリング), 伊藤靖雄, 梅沢晃司 (ダイヤコンサルタント), 高見智之, 及川典生 (国際航業), 山田知寛(日本工営), 渋谷保, 増田由紀子 (日 特建設), 熊井直也 (国土防災技術)，山本佑介，村上智昭，小林俊樹 (復建技術コンサルタント), 渡邊修(水文企画), 池田浩二(東北開発コンサル夕ント), 加茂圭祐 (応用 地質） 以上 20 名，6/9 調査/八木浩司 (山形大),熊井直也，山村充，高橋康平(国土防災技術)，渡邊修(水文企画)，6/15 調査/熊井直也，山村充(国土防災技術) 
必要である。

また, 変動域の地内中央部に深い沢が 発達し, 斜面上方の集水域から地すべり 地内に恒常的な地表水の流下がある。そ の沢沿いの渓岸侵食も地すべりの不安定 化に関与している可能性がある。

亀裂は最初に東側斜面に確認され, 住 宅地のある西側に変状が拡大した経緯が ある。沢を挟んで東西の斜面の移動方向 が若干異なることが, $5 / 31$ と $6 / 9$ のド ローンによる空撮写真の比較から判明し ている（図－3）が，東側と西側が概ね 一体化して移動している状況より，す心゙ り面は沢底より深いことが予想できる。

末端の沢の河床に地層（新第三系中新 統荻野層, 泥岩・凝灰岩）が露岩し, 姿 勢は東傾斜 $\left(\mathrm{N} 14^{\circ} \mathrm{W} \cdot 17^{\circ} \mathrm{E}\right)$ である。 変動域の西側は, 流れ盤方向の東側（地
層の傾斜方向）に移動方向を向けつつも, 変動域全体はほほ阿賀川に向かう走向に 近い方向に移動している。つまり，低角 度のすべり面で移動していることになる。 東西の断面でみると地すべり移動体の形 状が左右非対称で, 東側のほうがすべり 面が深く, 河床にすべり面が潜っている 可能性がある。

変動域の東側に花崗岩類が分布し, 堆 積岩との地質境界をなす断層面が左側部 を規制している。阿部（1996）は当地区 周辺の地すべりの地質構造を調べており, 花崗岩体の隆起に伴う断層運動によって 地層境界付近で堆積岩が裮曲しているこ とを指摘している（図-4）。その向斜 構造が地すべり形状や移動方向を規制し ている可能性がある。

末端の沢沿いにみられた渓岸崩壊の底

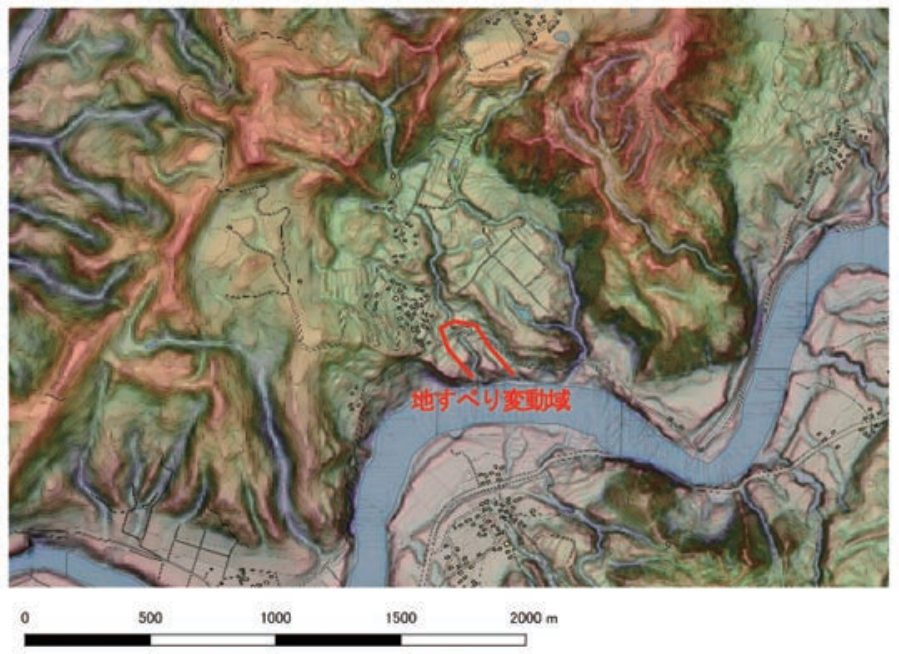

図一2 揚津地すべり周辺の地形図

（東北開発コンサルタント池田氏作成, 国土地理院 $5 \mathrm{mDEM}$ 使用)

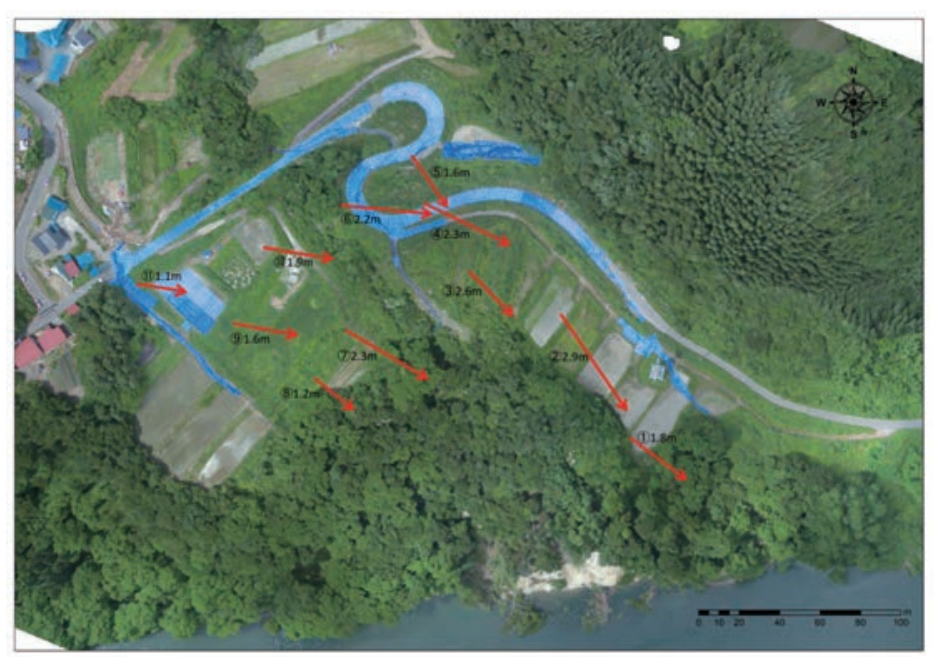

図一 32 時期のオルソ空中写真からの移動方向, 水平移動量の推定 （5/31復建技術コンサルタント撮影写真と6/9国土防災技術撮影写真を使用）
面に凝灰岩起源の白色粘土が確認された。 当地区から $2.5 \mathrm{~km}$ 東北東に位置する抜戸 地すべりでは，スメクタイトに富む膨潤 性凝灰岩がすべり面を形成し，5前後の 残留せん断抵抗角の試験データが報告さ れている（山崎ほか, 2003）。当地区のす べり面も，同様の土質特性を有している 可能性が高い。

\section{4. 第 1 回目調査結果を受けての提言}

$5 / 31$ の現地調査結果を受けて, 調査 方針や応急対策について，以下の提言を 行った。

・二時期の航空レーザー測量 (LP) デー 夕との比較や, ドローン空撮によるオル ソ画像の比較，地内の移動杭観測などに より，移動方向を早急に把握し，ボーリ ング調査の配置計画などにも役立てる必 要がある。

・地すべり移動体の移動方向や移動量が 正しく反映される位置に地盤伸縮計を増 設した上で，移動体の内部や周囲につい てGPS観測を追加しての地盤変動監視を 検討したい。

・東側ブロックは西側に先行して動いて おり，末端部の河岸斜面の不安定化も進 んでいる。現在伸縮計は西側ブロックの みに設置されていることから，東側の詳 細な動態観測（変位量のモニタリング） も必要である。

・阿賀川の横断測量を実施し，既往デー 夕と比較することも必要である。

・阿賀川の水位については，地すべりの 末端から約 $1.2 \mathrm{~km}$ 下流にある東北電力の ダムで管理をしており変化がそしい可能 性もある。しかし，豪雨時などは増水す る可能性もあるため阿賀川の水位変化も チェックすべきである。

・ボーリング調査は，東側・西側ブロッ ク両方で行う必要があるが, 特に東側ブ ロックはすべり面が深く，移動体の形状 が左右非対称と推定される。調査測線は, 移動方向を反映し, すべり面が最も深く なりそうな断面位置での設定が望ましい。 また，横断方向のすべり面形状も把握で きるような調査孔配置にする必要がある。 ・住宅側への地すべりの拡大監視を目的 に，地外でのボーリング調査，動態観測 用の計器設置も実施したほうがよい。

・地すべりに関与した地下水の流入経路 

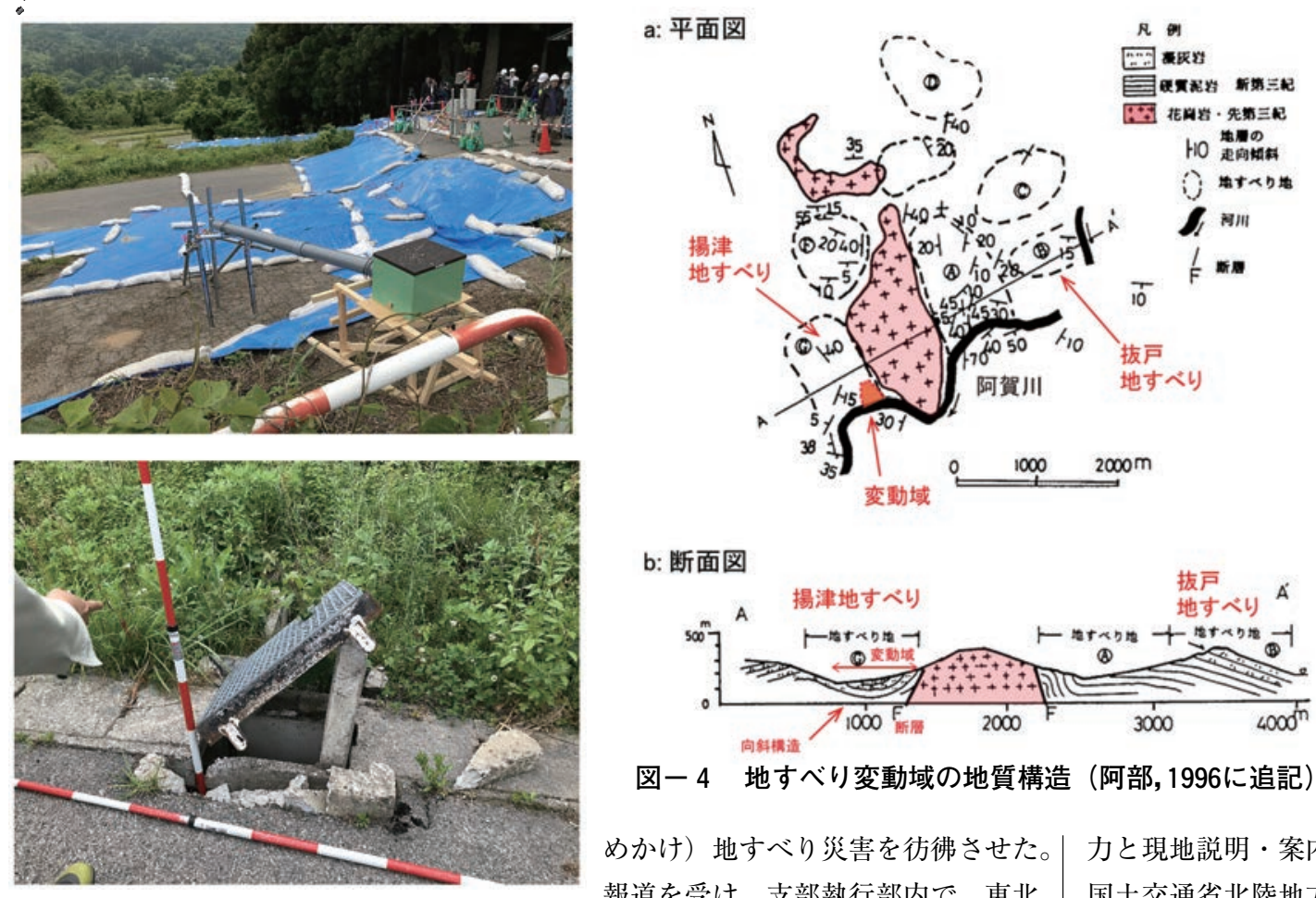

図ー4＼cjkstart地すべり変動域の地質構造（阿部, 1996に追記）

写真ー 1 地すべり変状 $(5 / 31$ 撮影 $)$

を調査し，地下水排除工の配置計画に役 立てる必要がある。ボーリング調査だけ でなく，地表調査でも明らかにできるこ とがある。例えば, 活動中のブロックの上 流部からブロック端部までの沢流量の変 化を調べることで, 沢水からの地下水供給 の有無などの状況が分かる可能性がある。 ・西側ブロックの伸縮計は, $5 / 31$ 現在 3 $\mathrm{mm} / \mathrm{h}$ の移動速度を記録しており，一般 的な避難の管理基準值 $(4 \mathrm{~mm} / \mathrm{h})$ に近 い状況にある。伸縮計のデータをリアル タイム監視し, 崩壊予測式（三次クリー プへの進行の判断）などを用いて，避難 計画に活用する必要がある。

・現在の活動状況では, 調査ボーリング 孔がすぐせん断されてしまう。パイプ歪 計などが断線した場合にも継続監視でき るようにワイヤーも設置し，地中伸縮計 として観測できることが望ましい。

・近く梅雨期に入ることから, 応急対策 工事もできることから進めていくことが 望ましい。沢水の迁回, 水抜きボーリング, 山形県の七五三掛地区で発生した地す心゙ りの対策事例なども参考に, ディープウェ ルによる強制排水なども候補と言える。

\section{5. おわりに}

今回揚津地区で発生した地すべりは, 2009年に山形県で発生した七五三掛（し
めかけ）地すべり災害を彷彿させた。 報道を受け, 支部執行部内で, 東北 支部として早期に視察を行って，管 理者への経験の共有を図ることが重要と の判断があった。

6 月初旬からは福島県によって沢の水 のバイパス工事やディープウェルの設置 が進められた。その結果，国土交通省北 陸地方整備局が行ったGPS観測で，一時 は $25 \mathrm{~mm} / \mathrm{h}$ を越える移動速度を示した東 側の変動域も $6 / 22$ 現在 $0.1 \sim 0.2 \mathrm{~mm} / \mathrm{h}$ にまで減速している。

阿賀野川・阿賀川流域は地すべりの多 発地帯として知られ, 過去に空中写真判 読をもとに地すべり地形再活動危険度評 価なども取り組まれてきた（八木ほか, 2009）。今回再活動を起こした揚津地区 の地すべりに対してどのような評価を行 えていたかなども再検証が必要であろう。 空中写真だけでなく, 現在普及している 航空レーザー測量データも危険度評価に 活用し, 精度を高めるような検討も今後 求められよう。また，4月の東北支部シ ンポジウムでは, 衛星SAR技術を用い て斜面変動の前兆を把握する技術につい て話題提供があったばかりであった。地 すべり災害の初動対応の面でそのような 最新技術の活用・普及が期待される。

\section{謝辞}

福島県会津農林事務所農村整備課, 喜 多方市高郷総合支所には, 調査へのご協
力と現地説明・案内をして頂いた。また， 国土交通省北陸地方整備局から地すべり 移動体のGPS観測デー夕を提供頂いた。 記して感謝申し上げます。

\section{引用・参考文献}

阿部真郎（1996）: 東北地方の新第三紀・泥 岩層における褶曲及び断層構造の成因と 地すべりとの関連性, 地すべり, Vol. 33, No. 1 , pp. $20-28$.

国際航業株式会社 (2018): 平成30年 5 月福 島県喜多方市地すべり災害. http : //www. kkc.co.jp/service/bousai / csr/disaster/ 201805_kitakata/index.html（参照日2018 年 6 月 10 日）

相楽涉 - 佐藤修 - 山邊康晴 $\cdot$ 大海寺勲 （2003）: 大規模地すべりの地下水流動特 性：福島県西会津町滝坂地すべりを例と して, 日本地すべり学会誌, Vol. 40, No. 2, pp. $138-144$.

相楽涉 - 丸井英明 - 吉松弘行 (2005)：大規 模地すべり地の地下水流動特性に関する 考察：東北地方の第三紀層地すべりを例 として, 日本地すべり学会誌, Vol. 42 , No. 1, pp. 51-62.

八木浩司 - 檜垣大助 $\cdot$ (社) 日本地すべり学 会平成14年度第三系分布域の地すべり危 険箇所調查手法に関する検討委員会 （2009）：空中写真判読とAHP法を用いた 地すべり地形再活動危険度評価手法の開 発と阿賀野川中流域への適用, 日本地す ベり学会誌, Vol. 45, No. 5 , pp. 358-366. 山崎孝成 - 岩㴊清任 · 須藤充 (2003)：膨潤 性凝灰岩に形成されたすべり面, 地すべ り. Vol. 39, No. 4, pp.434-435.

吉松弘行 - 相楽涉 - 菅野孝美 (2005) : 積雪 地域の地すべり地における長期的な地下 水位の変動予測, 日本地すべり学会誌, Vol. 49, No. 3, pp. 119-128.

（原稿受付2018年 6 月22日， 原稿受理2018年 7 月17日） 